\title{
A CONSTRUÇÃO DA NARRATIVA “UMA VIAGEM AO INFERNO”, DE BERILO NEVES, PELOS PRESSUPOSTOS DA TEORIA DO CONTO, EM EDGAR ALLAN POE
}

\author{
THE NARRATIVE CONSTRUCTION "A TRIP TO HELL”, BY BERILO NEVES, \\ THROUGH THE ASSUMPTIONS OF THE TALE THEORY, IN EDGAR ALLAN POE
}

\author{
Recebido: 22/10/2020 Aprovado: 11/12/2020 Publicado: 10/01/2021
}

DOI: $10.18817 /$ rlj.v4i02.2396

\begin{abstract}
Cleane da Silva de Lima ${ }^{1}$ Orcid id: https://orcid.org/0000-0003-4114-3924

Luzimar Silva de Lima²

Orcid id: https:// orcid.org/0000-0002-0919-6105
\end{abstract}

Resumo: O presente artigo analisa a unidade de efeito no conto "Uma viagem ao inferno", de Berilo Neves na perspectiva da Teoria do conto, de Edgar Allan Poe. Para tanto, utilizou-se o método hipotético-dedutivo com pesquisas bibliográficas, bem como trabalhos de fundamento teórico que estudam a estrutura do conto enquanto texto, criação, valor e estética como Poe (2011), Cortázar (2006) e Gotlib (1990). Desse modo, a construção do conto gira em torno dos assuntos instigantes sobre o inferno e as conotações sobre ele por meio da intenção do conto em gerar o máximo de efeito em seu leitor, afirmando o valor estético e criativo da narrativa.

Palavras-chave: Unidade de efeito. "Uma viagem ao inferno". Teoria do conto. Edgar Allan Poe

Abstract: The present article analyze the effect unit in the tale "A trip to hell", by Berilo Neves in perspective of the Tale theory, by Edgar Allan Poe. Therefore, the deductive hypothetic method with bibliography research was used, as well as the works of fundamental theorists who study the tale structure while text, creation, value and aesthetic such as Poe (2011), Cortázar (2006) and Gotlib (1990). Thus, the construction of tale revolves around thought-provoking subjects about hell, and the connotations about it, through the intention of the tale to generate maximum of effect in the reader, affirming the aesthetic and creative value of the narrative.

Key-words: Single effect. "A trip to hell" .Tale theory; Edgar Allan Poe.

\section{Introdução}

O conto é, conforme Poe (2011), uma narrativa breve por ter uma estrutura definida na economia do texto, compreendendo o ambiente, o tempo, o clímax, poucas personagens e o conflito girando em torno de um só assunto compactando todo o conto, assim como sua totalidade. Por esse viés, pode ser lido de uma só vez,

\footnotetext{
${ }^{1}$ Mestre em Letras com ênfase em Literatura pela Universidade Federal do Piauí- UFPI, Especialista em Língua portuguesa e Literatura brasileira pela Faculdade Futura. Graduada em Letras-português pela Universidade Estadual do Piauí- UESPI. Integrante do grupo de pesquisa Literatura, Leitura e Ensino (UESPI). E-mail: necah.lima@hotmail.com

2 Doutoranda em Literatura pela Universidade Federal do Piauí. Mestre em Língua Portuguesa pela Universidade estadual do Piauí- Mestrado Profissional em Letras - PROFLETRAS. Possui graduação em Letras Língua Portuguesa pela Universidade Estadual do Piauí (2009), Licenciatura em Pedagogia pela Universidade Estadual do Piauí- UESPI (2014). E-mail: luzilii@hotmail.com
} 
sem ruptura ou intromissões externas, produzindo a emoção desejada do contista no seu leitor.

Dessa forma, o texto é intencional, pois almeja conquistar seu receptor pela leitura atenta e curiosa a qual deseja despertar. Para que haja a curiosidade do leitor, o escritor insere no texto assuntos relacionados aos fatos sociais a fim de compor uma verdade nas histórias, possibilitando ao receptor o sentido da narrativa.

Nessa perspectiva, o objetivo deste trabalho é analisar a unidade de efeito no conto "Uma viagem ao inferno", de Berilo Neves, na perspectiva da Teoria do conto, de Edgar Allan Poe. Compreendendo o fator criativo, imaginativo e o assunto escolhido para a composição da narrativa, sendo ela propositada a partir da linguagem e das personagens que compõem a história.

Por essa razão, a Teoria do conto, de Edgar Allan Poe, traz para a literatura o valor do texto em sua composição poética, a impressão e as emoções do leitor por meio da unicidade de efeito emanadas do conto, além da criação e inovação do escritor em produzir a narrativa, sendo tudo nela calculado para despertar reações várias em quem a lê.

Por conseguinte, a teoria referida aplicada no conto citadino de Neves possibilita ao leitor entender o fazer poético e o estético do texto, bem como a preocupação do escritor para suscitar a unicidade de efeito no leitor por intermédio do assunto instigante no conto sobre uma viagem ao inferno.

O artigo é dividido em duas seções: a primeira versa a respeito da Teoria do conto, por meio da unicidade de efeito e a composição do texto literário para prender a atenção do leitor. A segunda tece considerações sobre a análise do referido conto a partir dessa teoria, mediante a criatividade e inovação na construção da prosa curta e seu valor estético.

\section{A Teoria do conto, por Edgar Allan Poe}

Edgar Allan Poe nasceu nos Estados Unidos, em Boston, no ano de 1809. Faleceu na cidade de Baltimore em 1849. Foi contista, poeta, editor e crítico literário. A forma como enxergava a literatura 0 diferenciava de seus contemporâneos, pois "o romantismo de Poe era muito diferente dos que buscavam os seus compatriotas, e o plantador não simbolizava com eles mais que os literati de Nova York ou os homens de letras do Oeste". (CORTÁZAR, 2006, p. 136). A 
construção poética e crítica de Poe voltava-se para a criatividade, a personalidade e a percepção de análise sobre o tema da obra que pudesse levar o leitor para além daquilo que pudesse encontrar no texto.

Sobre sua tarefa como crítico, almejava ter sua própria revista, entretanto, não conseguiu. Por outro lado, obteve o destaque merecido nas revistas em que colaborava, distinguindo-se das correntes dominantes de seu país, por trazer uma análise crítica voltada profundamente ao texto, seja na sua estrutura, seja no seu efeito.

Poe buscava em seus estudos "aplicar à obra de arte uma tendência à análise, um sentimento de superioridade que o levava a se converter no árbitro do gosto literário de seu tempo e a uma altíssima exigência em matéria de estética" (CORTÁZAR, 2006, p. 139). São essas considerações que o crítico carregava para suas análises sobre os textos que criticava.

No livro Valise de cronópio (2006), Cortázar, no capítulo 5, discorre a respeito de Poe, enfatizando a influência literária e crítica do autor citadino. Pois segundo as informações colhidas do livro, sabe-se que nos Estados Unidos, entre os anos de 1830 a 1850, a antiga tradição de cultura que assegurava a velha geração fundadora da República estava se extinguindo. O romantismo e a filosofia alemã secundária influenciou o país, mesmo sendo pouco ou quase não mencionados. A nação estava dividida na controvérsia da escravidão, do industrialismo e de rumores de democracia. Por conseguinte, é nesse contexto histórico que Poe é influenciado pela filosofia europeia, pelo contato que teve com revistas inglesas e pelos escritores europeus. Ademais, conheceu Macaulay e Christopher North, interessando-se por Shelley, Keats, Byron Wordsworth e Coleridge, os quais foram responsáveis por seu amadurecimento literário. ${ }^{3}$

A construção social, literária e crítica de Edgar Allan Poe permitiu o amadurecimento de suas análises a respeito do fator poético e estético nos textos os quais analisava, possibilitando assim o surgimento do conto moderno no século XIX, sendo Poe o primeiro crítico dessa teoria. Sua análise sobre o conto, que possibilitou um caráter mais crítico a esse gênero, ocorreu com as resenhas sobre Twice-told tales, de Nathaniel Hawthorne, pelas críticas sobre a profundidade e os pontos culminantes de suas narrativas. Críticas essas publicadas na revista Granhan's

3Biografia Edgar Allan Poe enquanto crítico em CORTÁZAR, Julio. Valise de cronópio. São Paulo: Perspectiva, 2006. 
Magazine (KIEFER, 2011). Logo, são essas resenhas que abordam sua análise crítica a respeito do conto dando uma visão maior e sólida à teoria do conto moderno.

Poe percebe ao analisar a obra de Hawthorne que o autor era habilidoso em escrever suas narrativas. Ele construía as frases e as ideias de forma que podiam ser consideradas profundas. Os assuntos dos textos, por mais que fossem conhecidos, eram abordados de maneira inusitada que o fazia se diferenciar dos demais escritores, sendo inovador.

Por esse viés, o conto permite a imaginação, a articulação da linguagem, da imagem e dos fatos sociais que devem ser bem explorados pelo escritor. Dessa forma, para Poe (2011), o conto oferece o mais nobre talento, pois sua composição é intencional, arquitetada para provocar um só efeito no seu leitor. Os assuntos, personagens, elementos linguísticos, todos são bem articulados para atingir o máximo de emoção em seu receptor. Conforme Poe,

a respeito de que em quase todas as categorias de composição a unidade de efeito ou de impressão é um ponto da maior importância. Além do mais, está claro que esta unidade não pode ser totalmente preservada em produções cuja leitura não possa ser feita de uma só assentada. Podemos continuar a leitura de uma composição em prosa, pela própria natureza de prosa. (2011, p. 336).

O texto para instigar o leitor precisa ser calculado, logo o contista tem a pretensão de provocar o efeito que se espera no leitor. Dessa forma, a unidade de efeito partiria do próprio texto, ou seja, das estruturas dele mesmo, assim causando impressões sobre o que foi disposto pela leitura, produzindo o seu sentido por meio das reações suscitadas das quais se esperam de um grande conto. Logo, esse efeito profundo realizado no leitor, se torna intenso e duradouro, ou seja, a unicidade de efeito.

A teoria de Poe volta-se para a técnica, para a construção do texto e de mecanismos que podem efetivamente produzir alguma impressão no seu leitor. Consoante Cortázar (2006, p. 129), "tecnicamente, sua teoria do conto segue de perto a doutrina poética: também um conto deve partir da intenção de obter certo efeito". O objetivo de suscitar a comoção do leitor é um dos princípios para que um conto deva ser bem elaborado, articulando-se premeditadamente os fatos, as personagens, as palavras para que tudo possa ser vivido pelo leitor. 
Conforme Poe (2011), a composição do conto se torna superior a do poema, do ensaio e do romance por não ser lido em uma só assentada, devido sua extensão, perdendo sua totalidade a qual depende de uma leitura atenta. Logo, o romance, por ser longo, tem interrupções pelos interesses exteriores a ele, há a anulação ou redução das impressões do livro, reduzindo a verdadeira unidade. Já no conto breve pode haver a totalidade de sua intenção durante toda a leitura, porque não há influências exteriores, ou seja, cansaço ou rupturas. Assim sendo, o contista é habilidoso ao construir o conto com a finalidade de produzir efeito único e singular, buscando a satisfação. O conto é mais talentoso e refinado do que o ensaio. Para o crítico, o conto é superior também ao poema,

\begin{abstract}
de fato, enquanto o ritmo deste último é um auxílio essencial no desenvolvimento da ideia mais elevada do poema - a da beleza-, as artificialidades do ritmo são uma barreira intransponível ao desenvolvimento de todos os pontos de pensamento ou expressão que têm sua base na verdade. porém, a verdade é, frequentemente, e em grande parte, o objetivo do conto. (2011, p. 339).
\end{abstract}

Desse modo, o poema atinge a percepção do belo no seu leitor pelo ritmo e assunto. $\mathrm{O}$ conto constrói a noção de verdade transmitida, ligando-se à impressão, no que é sentido e podendo ser realizado no momento da leitura, trazendo a construção da surpresa e do impacto.

Segundo Poe (2011), quando trabalhou a composição do poema O Corvo, deixou claro que não foi meramente escrito e sim bem calculado para que pudesse atingir o seu leitor. $O$ texto foi feito passo a passo, arquitetado em cada parte, objetivando agradar ao gosto tanto da crítica quanto popular. Pensado primeiramente na extensão, foca a unicidade de impressão que seria mais forte se fosse breve. Com isso, a extensão do poema pode ser calculada matematicamente, ou seja, pela elevação ou excitação produzindo algum efeito. Dessa forma, a beleza é o ponto máximo do poema no qual constrói a impressão e o efeito desejado por meio da emoção do leitor, enquanto a verdade no conto é o objeto do conto.

Com isso, para Gotlib, "tais propostas de construção da obra em função de um efeito predeterminado, seja no poema, seja no conto, primam para a racionalidade." (1990, p. 22). É pensar o conto como forma de produção de emoção surgida pelos sentimentos que são aflorados pelo que é lido. Por conseguinte, tem pontos vantajosos sobre o poema e o romance. A leitura do conto não 
necessariamente tem de mostrar o belo, mas provocar reações que sejam percebidas e indagadas pelo leitor por meio de uma leitura atenta.

Para Poe (2011), o que constrói uma boa narrativa, pelas análises sobre os textos de Hawthorne, são "a invenção, a criação, a imaginação, a originalidade, características que, na literatura de ficção, certamente valem por todo o resto.". Desse modo, esses elementos são importantes porque constroem a inovação do assunto no texto, escrito por uma perspectiva diferente. Logo, o que torna o conto inédito é a forma como são elaborados os assuntos, de como são ditos, diferentemente do que o leitor já conhece.

Para Cortázar, o bom contista é "um boxeador muito astuto, e muitos de seus golpes iniciais podem parecer pouco eficazes quando, na realidade, estão minando já as resistências mais sólidas do adversário" (2006, p. 152). Destarte, deixa clara a necessidade de produzir efeitos por meio de sua linguagem e acontecimentos na narrativa.

Nessa perspectiva, consoante Poe (2011), a emoção é um dos elementos que produz a noção de novidade na narrativa, elemento esse importante para o crítico, assim, para o citadino autor; o texto tem sua originalidade literária se comparado à metafísica. O fator original corrobora esse ponto pelas combinações de novos pensamentos que promovem a novidade e o sentimento suscitado pela unidade de efeito.

Além dos assuntos empregados na história, o narrador também é uma figura importante para a narrativa, sendo ele uma das personagens que dialoga com o leitor. Portanto, "a arte de narrar é uma arte da duplicação; é a arte de pressentir o inesperado; de saber esperar o que vem, nítido, invisível, como a silhueta de uma borboleta contra a tela vazia. Surpresas, epifanias, visões." (PLÍGIA,2004, p. 114). narrador é um elemento importante para seduzir a pessoa leitora, bem como produzir experiências que antes não foram sentidas ou percebidas pelo leitor, promovendo uma soma de conhecimentos advindos do conteúdo lido a partir do deleite e da fruição estética.

Nesse sentido, Propp (1983) explica que o ato de narrar é uma atividade que pressupõe um ponto de vista. O narrador conta uma história mediante o que viu ou percebeu, também expondo pelo seu ponto de vista algo ao leitor. Ademais, o receptor conhecerá o conteúdo e os demais aspectos da narrativa pela voz do 
narrador e da percepção sobre as coisas ocorridas, em muitos casos, quem narra a história expõe seus sentimentos ou manipula o seu receptor.

Gotlib reflete que a Teoria do conto para Poe, "recai no princípio de uma relação: entre a extensão do conto e a reação que ele consegue provocar no leitor ou o efeito que a leitura lhe causa" (1990, p. 19). Desse modo, o assunto deve despertar no leitor as emoções que o contista deseja produzir por meio da leitura intensa, despertando emoções causadas pelos acontecimentos ocorridos na prosa.

Por conseguinte, o contista aplica "no discurso ficcional uma hora intensa e aguda da percepção" (BOSI, 1994, p. 09). Logo, o conhecimento social e psicológico do contista corrobora a escrita de um texto no qual se realiza por seus conhecimentos de mundo, de leituras, experiências e vivências. Portanto, a compreensão do texto pelo leitor é atingida nesse diálogo entre literário e social.

Assim sendo, o fazer poético do conto possibilita a impressão, investigações e efeito no leitor provocando inquietude, satisfação a partir da interação com o texto por intermédio da leitura. O escritor, de acordo com Cortázar (2006), pelos seus valores humanos e literários ao arquitetar a narrativa, sofre as influências daquilo que cria, além de carregar para dentro do texto conhecimentos seus, a formar suas histórias.

Nessa perspectiva, a novidade na narrativa desperta a emoção do leitor, fazendo-Ihe imaginar e atribuir sentido ao texto, aguçando o seu mais intenso prazer, além de conhecimento. Este mesmo caráter de novidade possibilita-lhe enxergar aquilo que não conseguia compreender, contribuindo para um novo ponto de vista. Por esse viés, consoante Poe (2011), a seriedade e a verossimilhança são os pontos de máxima para a ficção. Os contos narram fatos que fazem parte do meio social de forma mais poético, e o desejo do escritor é fazer o leitor sofrer a impressão calculada, além de deixá-lo sob o controle do conto quando o efeito único Ihe atinge. Destarte,

um hábil artista literário construiu um conto. Se é prudente, não terá elaborado seus pensamentos para ajustar incidentes, senão que, depois de conceber cuidadosamente certo efeito único e singular, inventará os incidentes, combinando-os da maneira que melhor o ajudem a lograr o efeito preconcebido. (POE, 2011, p. 365)

efeito - sendo um dos maiores objetivos do contista- acontece quando as reações desejadas e calculadas pelo conto atingem o receptor ao prender sua atenção desde o início do conto até o final, potencializando sua emoção, comoção e 
comportamentos que possam ser despertados a partir daquilo que foi lido bem como construindo conhecimento.

Desse modo, o valor estético e poético do conto é sentido e concretizado pelo leitor. Logo, o conto "é significativo quando quebra seus próprios limites com essa explosão de energia espiritual que ilumina bruscamente algo que vai muito além da pequena e às vezes miserável história que conta". (CORTÁZAR, 2006, p. 153). A narrativa pode provocar um intenso anseio que a transgrida, produzindo um novo sentido para o conto ou a ressignificação do que foi lido.

Dessa forma, Poe (2011), no ensaio A filosofia da composição, diz que para construir uma história, pensa primeiro na ideia da emoção. Portanto, é preciso pensar no assunto, nas impressões, e assim, dentro de si, as melhores combinações de eventos ou tom, além da construção das personagens em suas ações e reações.

A ação e a reação são elementos que o texto comporta para construir algo sólido e edificante, objetivando seu maior número de emoção. O conto por ser breve compacta todos os sentidos, além de aguçar o imaginário do seu leitor que ao longo do texto vai seguindo as pistas deixadas, desenvolvendo seu conhecimento sobre o que foi lido. Também é por meio da fruição estética produzida pelo texto que ele capta aquilo que o texto tem de diferente dos demais lidos.

\section{A unicidade do efeito em "Uma viagem ao inferno", de Berilo Neves}

O contista Berilo Neves nasceu em 1899, na cidade de Parnaíba, no Estado do Piauí. Faleceu em 1974, na cidade do antigo e extinto Estado da Guanabara, no Rio de Janeiro, local que trabalhava como escritor, jornalista, além de ter sido farmacêutico. Neves conquistou um vasto grupo de leitores no Brasil nos primeiros anos do século XX. Foi escritor de ficção científica, de poemas, de crônicas, contos, entre outros. Neves abordava em seus contos aspectos sociais, modernidade e humor, os quais possibilitavam o interesse dos seus receptores pelos conteúdos curiosos que podiam gerar o efeito único a partir da leitura das narrativas humorísticas.

Sua obra beste-seller, A Costela de Adão, foi um dos seus livros mais lidos em seu período de surgimento, publicada em 1929, conquistando várias edições. Os contos compreendiam assuntos que envolviam mulheres e ciência, assim como uma 
linguagem humorística, irônica e maliciosa que despertava diversas emoções em seus leitores.

Dessa forma, a narrativa "Uma viagem ao inferno" emprega fatos sociais ligados à fantasia e à noção de futuro que podem despertar o imaginário do seu leitor. Para Poe "o escritor do conto em prosa pode levar seu tema a uma vasta variedade de modos ou inflexões de pensamento e expressão (raciocínio, por exemplo, o sarcástico, o humorístico)". (2011, p. 339-340). Neves, para compor sua narrativa, utilizou-se de assuntos que vão desde a imagem do diabo ao avanço científico, usando a ciência como assunto de todo o conto.

O conto citadino se passa no século XXXV, com avanços científicos, como o liame entre o mundo material humano e imaterial. Os humanos podiam conviver com os mortos sem terror. Os defuntos não provocavam mais medo nas pessoas como antes, afinal eram seres inofensivos. Pois, "o admirável progresso das sciencias psychicas nos ultimos 50 annos trouxe-nos, neste limiar do seculo XXXV em que vivemos, á annulação integral das fronteiras entre o mundo physico e o mundo espiritual." (NEVES,1936, p. 83) ${ }^{4}$

O avanço tecnológico é o assunto mais marcante do conto. Por essa razão, a criação da narrativa está apoiada nessa revolução científica da humanidade, porém com perspectivas diferentes, construindo um mundo divergente do que já se é habitual, ou melhor, conhecido pelo leitor. A imaginação, como um dos pontos fortes na narrativa de Neves (1936), possibilita que o receptor perceba a ciência como viabilidade de comunicação entre os dois planos efetuada por aparelhos aéreos específicos para essas viagens que ocorriam entre os dois ambientes.

A história se torna instigante por meio das novas formas de articulação social que estão marcadas no ambiente Inferno, local que era inacessível ao ser humano enquanto vivo viajar até lá e conversar com o Diabo. São essas ideias que podem despertar a curiosidade do leitor, pela maneira como o autor formula a linguagem e as personagens. Dessa forma, o jornalista, narrador da história, relata que

O intercambio intellectual e moral entre os dous mundos tem sido feito nestes ultimos annos, por meio de apparelhos aereos dotados de grande raio de acção, e capazes de levar e trazer, em algumas horas, as cartas de amor ou de reclamações que os viventes e defuntos se mutuam á taxa modica $1 \$ 000$ por 20 grammas de peso... (NEVES, 1936, $p, 83$ )

\footnotetext{
${ }^{4} \mathrm{~A}$ grafia contida na citação de trechos do conto será fiel à gramática da época de 1936.
} 
É nessa ideia de criação de aparelhos aéreos que pode suscitar algum efeito no leitor, o que produz questionamentos e percepção sobre a invenção e descobertas tecnológicas que unem os dois mundos. Destarte, o conto pode ser excitante por haver novidade no assunto abordado pelo contista. Para Poe (2011), o conto promove reação no leitor quando há invenção, criatividade e uma força imaginativa os quais valem como um todo na literatura de ficção.

Por conseguinte, Neves (1936) ao articular uma tecnologia avançada com o cotidiano do homem, emprega no conto esse artifício humano de comunicação, como uma maneira de compreender os ocorridos anteriores e ligá-los à humanidade. Tema que pode causar curiosidade devido os assuntos serem considerados, de todo já conhecido, mas com uma abordagem diferente.

O conto de Neves (1936) permite ao leitor construir as cenas a partir das descrições do narrador sobre esse fato científico. A leitura atenta pode proporcionar o interesse do leitor em desvendar a história pela forma como é narrada, pelos sentimentos e reações suscitados pelo conto, assim também pela linguagem que desperta a curiosidade em conhecer os conteúdos instigantes no texto.

Dessa forma, a narrativa de Neves (1936) apresenta os fatos e personagens com poucas descrições, em que pela economia dos aspectos narrativos, o conto "[...] trata-se de conseguir, com o mínimo de meios, o máximo de efeitos" (GOTLIB, 1991, p. 20). O conto de Neves (1936) não se aprofunda muito no psicológico das personagens e nem nos detalhes do ambiente. Por outro lado, possibilita ao leitor criar uma imagem própria sobre a narrativa por meio da ciência empregada no texto.

No conto, o jornalista relata que se um homem do século vinte alcançasse essa tecnologia, enlouqueceria se soubesse das entrevistas que são realizadas com poetas, filósofos, entre outros intelectuais, como Pasteur, Galileu, Nero e Sócrates. O narrador destaca esses intelectuais acentuando suas descobertas e conversas com eles.

Desse modo, o escritor seleciona os fatos e personagens que podem instigar o leitor, a fim de atraí-lo para a narrativa. Logo, o receptor, por sua vez, é esse que experimenta o texto mediante suas experiências de vida, social e de leituras a completar o texto e produzir seu sentido. É nessa linha que a obra pode provocar impacto e reações, como de surpresa, curiosidade, espanto, entre outros, com o intuito de produzir o máximo de efeito em seu receptor. 
Nesse sentido, no conto breve, "o autor pode levar a cabo a totalidade de sua intenção, seja ela qual for. Durante a hora de leitura, a alma do leitor está nas mãos do escritor. Não há influências externas ou extrínsecas, produzidas pelo cansaço ou pela interrupção". (POE, 2011, p. 338). O leitor fica atento aos ocorridos da narrativa, consumindo o texto de uma só vez. Assim, atinge a unicidade de efeito emanada pelo que foi lido.

A narrativa de Neves (1936), por ser curta, compacta todo o tema que deseja mostrar ao seu leitor, construída com fatos triviais, porém, a forma como maneja a narrativa e os incidentes é a que lhe torna sedutora. Nessa perspectiva, todo o conto é fechado em suas ideias, girando em torno do tema que forma todo o assunto da história, com uma leitura que somente acontece sem ruptura. É nessa ideia que o contista pode ter força em prender a atenção do leitor, objetivando envolvê-lo ao máximo na leitura, tornando-a agradável e satisfatória.

Nessa perspectiva, o jornalista é uma das personagens que interage com o leitor, pois narra sua aventura, ou melhor, a empreitada para ir ao inferno entrevistar o Diabo, podendo ser um dos momentos que possibilita o efeito no leitor e ativa sua curiosidade, como no diálogo do jornalista com o piloto: "_ Aonde vamos? perguntou o capitão subindo para a nacelle do apparelho. __ Ao inferno, meu capitão e a 1.900 kilometros, se faz favor..." (NEVES, 1936, p. 85).

O jornalista narra à medida que percebe o seu mundo material, suas experiências frente aos fatos corriqueiros em sua sociedade e a aventura em conhecer o inferno. São por essas descrições que a leitura fica condensada a opinião do narrador, o qual conta os fatos mediante suas experiências, em que o leitor, por intermédio dessas informações selecionadas por ele, pode construir seu próprio ponto de vista e o valor estético do texto.

Nessa perspectiva, a construção do conto está atrelada à sensibilidade e à compreensão de mundo, cultura e criatividade do contista para seduzir o leitor. Pois, conforme Cortázar,

o escritor é o primeiro a sofrer esse efeito indefinível, mas avassalador de certos temas, e que precisamente por isso é um escritor. Assim [...] o escritor reage diante de certos temas, da mesma forma que seu conto, predeterminado pela aura, pela fascinação irresistível que o tema cria no seu criador. (2006, p. 156). 
O escritor, por meio de sua experiência e criatividade, para compor sua narrativa, dispõe de seu conhecimento de mundo social, intelectual, linguístico e ideológico, permitindo ao leitor experimentar emoções novas pelo tema e assunto proposto na narrativa.

No texto, o narrador para surpreender o chefe, tem a ideia de entrevistar o Diabo, posto que, assim, seria preciso viajar ao inferno para conseguir uma matéria jornalística com o senhor das trevas. Sobre a viagem, o jornalista relata que:

Partimos para o inferno, região escura que permanecia, até então, mais ou menos fóra do alance dos nossos melhores apparelhos do ar. Durante 12 horas varámos os ares como uma bala, aspirando oxygenio artificial para compensar os effeitos physicos da rarefacção atmospherica. O capitão Meira não pronunciava uma palavra. Era valente como poucos. [...]. O inferno é um lugar saudavel, situado na constelação Eva, descoberta há vinte annos. (NEVES, 1936, p. 85).

Neves (1936) elabora a narrativa elencando uma das personagens mais alegóricas da religião ocidental, o diabo. Situa a imagem que o narrador tem do inferno como um lugar calmo e tranquilo, além da avançada tecnologia. São essas descrições que o autor lança ao leitor, que pela curiosidade e sua experiência estética, constrói seu ponto de vista sobre a ciência na narrativa e o assunto principal: a viagem do jornalista ao inferno para uma entrevista com o diabo.

Por esse viés, no enredo há economia na descrição do lugar e das personagens, além das ações e comportamentos deles, mas que permitem ao leitor construí-los por meio do narrador. De acordo com o jornalista, quando chegou ao inferno, percebeu que era silencioso, deu-lhe a impressão oposta à qual conhecia. Os seres que viviam naquele ambiente- diabos vertidos de vermelho-, estavam curiosos com as suas vestimentas. O Diabo logo veio exalando seus perfumes caros. Era simpático e tinha um riso irônico.

A personagem Diabo no conto é caracterizada como um ser elegante e gentil. A composição da personagem quebra a sua descrição já conhecida. $O$ efeito que pode provocar no leitor está na forma como são elaborados o comportamento e as ações dele; sendo, de certo, empregado como vítima da mulher, por meio do humorismo que cria todo o discurso do Diabo.

A descrição do ambiente torna o conteúdo do texto inovador, visto que o inferno é um dos lugares mais abomináveis conhecidos pela religião ocidental. As características desse lugar são modificadas no conto como lugar "saudável". Assim, 
consoante Poe, "tudo que Ihe dá uma emoção tão novidadeira quanto agradável parece-lhe original, e aquele escritor capaz de lhe proporcionar isso será original". (2011, p. 353).

Percebe-se a seriedade da composição do conto, ao mesmo tempo da verossimilhança com os aspectos sociais empregados na narrativa que possibilitam produzir efeitos estéticos no leitor. Nesse viés, o autor almeja a surpresa, a curiosidade, questionamento e o valor de novidade, em imaginar um lugar monstruoso em paraíso - por sua calmaria-, podendo ocorrer a unicidade de efeito. O conto desenvolve uma imagem da ciência, dos fatos sociais, dos espaços real e fantástico que englobam a imagem do diabo, além do seu comportamento no conto que foge daquele conhecido pelo leitor.

É por intermédio dessas declarações que situam o receptor na narrativa. Segundo Poe (2011), o conto concentra e acende os sentimentos no leitor, disseminando suas emoções conforme o seu ânimo. As apresentações do ambiente e das personagens permitem ao receptor se aproximar da narrativa, construir imagens mediante seus conhecimentos e experiências de leitura que the possibilitam experimentar o texto. No conto, o jornalista explica seu primeiro contato com o Diabo:

Ao saber que era jornalista abraçou-me com alegria, e confessou a sua admiração pela imprensa, "a grande alavanca do progresso e o maior alliado do inferno, na terra", disse-me, textualmente. Offereci-lhe o ultimo exemplar da "Tribuna do Rio", que elle mandou guardar com cuidado, "para ler mais tarde". (NEVES, 1936, p. 86)

Neves (1936) torna o conto instigante pela forma como as informações sobre - Diabo são construídas, elaborando novos significados sobre sua existência. A maneira como arquiteta o diálogo do narrador com o dono das trevas é reforçada pela sua admiração pela imprensa, sendo um dos fatores mais interessantes e de proximidade da personagem com o homem. Neves cria uma conexão entre imprensa, o Diabo e a tecnologia que possibilita a compreensão dos acontecimentos na narrativa pela forma como os fatos são relatados pela voz do jornalista, figura ambiciosa que articula sua viagem premeditada e sua entrevista, o que possibilita reações várias no leitor.

A construção da nova versão sobre o diabo é percebida na voz do jornalista a partir de sua própria experiência adquirida pelo contato com ele. O narrador fica admirado em perceber que no inferno não tinha sofrimentos, "pensava que se 
depararia com sofrimento, 'mulheres desgrenhadas' pagando as trahições feitas aos homens, na terra. [...] mulheres infieis marcadas a fogo com palavras infamantes. $E$ nada disso encontro nos seus domínios, meu caro sr. Diabo." (NEVES, 1936, p. 86).

O conto de Neves além de mostrar a calmaria do inferno, destaca a mulher sendo um dos percalços do diabo, tudo produzido por meio do humorismo. São opiniões como essas das personagens marcadas na ironia, no humor, na ciência que permitem a narrativa ser sentida mediante a leitura realizada, a qual provoca sentimentos variados ao ser lida do início ao fim. Desse modo, Poe (2011) reflete que se no texto há novidade, há originalidade. Nesse contexto, Neves trata na narrativa de assuntos com uma nova imagem a este ser, atribuindo a ele novas condutas que pode provocar e divertir o leitor por intermédio da história.

Desse modo, para Poe (2011), o artista pensa na escolha de uma impressão ou efeito que torne a história apreciável a quem a lê. No conto de Neves (1936), o Diabo tem o poder de fala sobre sua experiência no inferno, que, por sua vez, explica ao jornalista o quanto aquele ambiente estava mudado. Havia tormentos, mas tudo acabou, já estava envelhecendo. Apagou os caldeirões, e os ferros de marcar as mulheres estavam enferrujados. Tudo isso por causa e culpa delas, como também dos ladrões. Entretanto, mais delas.

_ Malditas? Quem sãos as malditas, sr. Diabo?

- Não atinou ainda? Nem parece que é homem de imprensa! As mulheres, homem... as mulheres! Desde Eva, quase todas as que vinham do mundo estavam aqui... Era uma confusão, uma falaria, um inferno, meu caro! Ninguém se entendia. Havia indisciplina, intriga, conspiração entre os diabos. Acabei cansando... e expulsei-as. [...]. Aqui não me entra mais nenhuma. Não imagina como isso está bom. Que paz, que serenidade! Parece um sanatorio. Até engordei, acredite!(NEVES, 1936, p. 87).

No conto, a personagem Diabo articula a imagem da mulher como a sua ruína, uma das cartadas na narrativa para impactar o seu leitor, almejando efeitos que possam suscitar pela leitura o efeito estético por meio do seu humorismo. A narrativa de Neves (1936) por ser breve possibilita ao leitor uma leitura atenta dos conteúdos como traição, confusão ou desordem que colocam as mulheres como maliciosas.

Neves cria em seu conto mulheres que infernizaram o Diabo, sendo ele vítima delas. São descrições como essas que produzem a unidade de efeito do conto, as quais podem impactar, provocar, aborrecer, divertir seus leitores por meio 
das representações dessas personagens estruturadas na narrativa e construídas no humor.

No final do conto, o jornalista consegue fotografar o Diabo. À volta para casa foi mais demorada, pois "no regresso, gástamos mais duas horas do que na ida. $E$ ' que o capitão Meira, typo completo de homme â femmes, divagava subindo e descendo, na pista do inferno, do outro - o das mulheres...". (NEVES, 1936, p. 87). Nesse sentido, o caminho do lado das mulheres era mais tenso.

Dessa forma, o conto de Neves (1936) proporciona impressões e aguça a expectativa do leitor por intermédio da leitura, tornando- se inovador pela maneira como elabora os conteúdos já conhecidos pelo leitor, renovando-os por um ponto de vista criativo e imaginativo. A narrativa pode despertar o efeito desejado a ser alcançado pela composição das personagens, do ambiente e do assunto: a viagem ao inferno para entrevistar o Diabo que já se torna interessante pelo título.

\section{Considerações Finais}

A narrativa de Neves (1936) explora assuntos, como a tecnologia revolucionária alicerçada no humor e na ironia, os quais são elaborados num liame que gira em torno da entrevista do Diabo. É pela linguagem na narrativa curta que o autor pode conseguir a totalidade do seu conto, pois a leitura pode ser realizada de uma só vez, sem ruptura. As descrições dos fatos e das personagens constroem a compreensão do conto pela imaginação do leitor e do efeito suscitado a partir da leitura da história.

A Teoria do conto, por Edgar Allan Poe, possibilita compreender o valor criativo, imaginativo e estético do conto, bem como a unicidade do efeito e impressão que o conto breve pode suscitar no leitor, além da construção da narrativa sendo elaborada para despertar a emoção, comoção desejada que se objetiva alcançar pela história.

Por conseguinte, o valor criativo da narrativa é percebido na renovação da personagem Diabo, de suas características que destoam daquelas já conhecidas, além do comportamento das personagens que são importantes para a compreensão do leitor. Também pelo tom humorístico e irônico do autor que mescla o real com o irreal, possibilitando a impressão e efeitos no seu receptor, os quais permitem o valor literário e criativo do texto. 


\section{Referências}

BOSI, Alfredo. O conto Brasileiro contemporâneo. 10. ed. São Paulo: Editora Cultrix, 1994.

CORTÁZAR, Julio. Alguns aspectos do conto. In: CORTÁZAR, Julio. Valise de cronópio. São Paulo: Perspectiva, 2006.p. 147-163.

GOTLIB, Nádia Battela. A Teoria do conto. São Paulo: Ática, 1990.

KIEFER, Charles. A poética do conto: de Poe a Borges- um passeio pelo gênero. São Paulo: Leya, 2011.

NEVES, Berilo. Uma viagem ao inferno. 7. ed. In: NEVES, Berilo. A Costela de Adão. Rio de Janeiro: Civilização Brasileira, 1936. p. 83-87.

PLIGIA, Ricardo. Teses sobre o conto e novas teses sobre o conto. In: PLIGIA, Ricardo. Formas breves. São Paulo: companhia das letras, 2004.

POE, Edgar Allan. A filosofia da composição. Tradução. Lia Viveiros de Castro. 2. ed. Rio de Janeiro: 7 Letras, 2011.

POE, Edgar Allan. Segunda resenha de Edgar Allan Poe sobre Twice-told tales, de Nathaniel Hawthaniel Hawthorne. Trad. Charles Kiefer. In: KIEFER, Charles. A poética do conto. São Paulo: Leya, 2011.p. 333-348.

POE, Edgar Allan. Terceira resenha de Edgar Allan Poe sobre Twice-told tales, de Nathaniel Hawthaniel Hawthorne. Trad. Charles Kiefer. In: KIEFER, Charles. A poética do conto. São Paulo: Leya, 2011.p. 349-368.

PROPP, Vladmir. Morfologia do conto. Tradução: J. Ferreira; V. Oliveira. Lisboa: Veja, 1983. 